\title{
Evaluation of the Effects of Sensory Denervation on Osteoblasts by ${ }^{3} \mathrm{H}$-Proline Autoradiography*
}

\author{
D.J. Chiego, Jr.** and I.J. Singh \\ Department of Anatomy, New York University Dental Center, New York, N.Y., USA
}

\begin{abstract}
Summary. The inferior alveolar nerve was unilaterally resected in 30-day-old mice; other animals were unilaterally sham-operated. At $15,30,60,90$, or 150 days after surgery, the mice were injected with $2 \mu \mathrm{Ci}$ of ${ }^{3} \mathrm{H}$-proline (sp. act. $1.0 \mathrm{Ci} / \mathrm{mM}$ ) per $\mathrm{g}$ of body weight and killed 15,30 , or $60 \mathrm{~min}$ later. Autoradiographs were prepared from $5 \mu \mathrm{m}$ decalcified sagittal sections of mandibles and grain counts made over periosteal osteoblasts mesial to the first molar. In denervated mandibles, osteoblasts incorporated less isotope compared to controls with differences being maximal at the early intervals. These differences became attenuated with time, possibly due to an intrinsic compensatory mechanism, secondary to neurotrophic regulation.
\end{abstract}

Key words: Autoradiography $-{ }^{3} \mathrm{H}$-proline - Osteoblasts - Denervation

Despite the large volume of reported research, the function of nerves in osseous tissues remains unclear (Reviews by Ascenzi and Bell 1972; Dubner et al. 1978). A large body of information points out the trophic functions of innervation though not necessarily in bone. Most of this evidence has been derived from studies of denervated muscle, taste buds, and regenerating amphibian limbs. Both sensory and motor fibers are able to maintain limb regeneration although a larger number of motor fibers appears to be necessary (Singer 1952). The intensity of regeneration is apparently determined by the number of nerve fibers present (Guth 1969). If nerves are allowed to grow into an amputated aneurogenic stump, regeneration is accelerated (Yntema 1959). Thornton (1968) found that limbs that develop in the absence of nerves can regenerate without a nerve supply, but when placed in contact with nerves, they become nerve-dependent for subsequent regeneration. Following

Send offprint requests to: Dr. I.J. Singh, Department of Anatomy, New York University Dental Center, 345 E. 24th Street, New York, N.Y., 10010, USA

* Supported in part by NSF grant GU-3566

** Present address: Dental Research Institute, University of Michigan, School of Dentistry, Ann Arbor, Michigan, 48109, USA 
denervation, Singer and Craven (1948) reported an increased mitotic rate in regenerating salamander limbs, but Robbins (1967) observed an inhibition of mitotic activity in the denervated frog tongue.

Although available evidence is inconclusive, Moss (1972) suggested that the sensory nerves in bone may serve a neurotrophic function. The present study investigated the influences of the sensory innervation of bone on the modulation of osteogenic-cell activity.

\section{Materials and Methods}

Seventy-five CF-1 mice, 30 days old, and of both sexes were used. Animals were anesthesized with sodium pentobartibal $(5 \mathrm{mg} / 100 \mathrm{gm}$ body wt). A unilateral skin incision was made extending from the distal aspect of the mandibular angle anteriorly for about $1.5 \mathrm{~cm}$. The masseter muscle at its insertion was similarly incised, retracted, and the root apex of the mandibular incisor visualized. The inferior alveolar nerve could be seen beneath the cortex immediately superior to the tip of the incisor. At this age, the cortical bone above the inferior alveolar nerve was thin and easily broken with sharp forceps. The nerve was freed from the accompanying vessels and approximately $2 \mathrm{~mm}$ of it was removed. Muscle and skin incisions were closed with 3-0 surgical silk. Other animals were sham-operated. During the sham procedure, the surgical procedure was carried out as follows: Cortical bone above the inferior alveolar nerve was broken; the nerve was visualized but not cut. The contralateral side in each animal served as an untreated control. Fifteen animals were killed at each of the five time periods: $15,30,60,90$, or 150 days after unilateral denervation or sham procedure. Prior to sacrifice, the animals were injected intraperitoneally with $2 \mu \mathrm{Ci}$ per g body weight of ${ }^{3} \mathrm{H}$-proline (specific activity $1.0 \mathrm{Ci} / \mathrm{mM}$; Schwartzmann Radiochemicals, Orangeburg, N.Y.). Three experimental and two sham animals were killed at 15 , 30 or $60 \mathrm{~min}$ after ${ }^{3} \mathrm{H}$-proline administration.

Mandibles were bisected at the symphysis, fixed in neutral buffered formalin for $24 \mathrm{~h}$, decalcified in $10 \%$ EDTA (ethylenediaminetetraacetic acid) at $\mathrm{pH} \mathrm{7.4,} \mathrm{embedded} \mathrm{in} \mathrm{parafin} \mathrm{and} \mathrm{sagittally} \mathrm{sectioned} \mathrm{at}$ $5 \mu \mathrm{m}$. Several slides per specimen, each slide containing 4 to 5 sections, were prepared. Autoradiographs were made by dipping slides in Kodak NTB-3 emulsion and an exposure period of 16 days. The slides were developed in Kodak D-19 developer, fixed in Kodak Rapid Fixer, and stained lightly with Harris' hematoxylin.

All slides were examined under oil immersion at $\times 1000$. Grain counts were made over periosteal osteoblasts mesial to the first molar. Grains were counted over 400 to 600 labeled cells for each time period. Cells with overlapping nuclear and/or cytoplasmic outlines were not included in the analysis. Background grain counts were made for each slide with a $21.15 \mathrm{~mm}$ Whipple disc. Cells showing grain counts above background values were considered to be labeled.

Data were analyzed by prewritten computer programs for Paired " $\mathrm{t}$ " tests and Linear regression analyses including comparison of regression lines. The experimental period was divided into 4 intervals: 15 to 30,30 to 60,60 to 90 and 60 to 150 days. Linear regression equations were fitted for each interval (Dixon and Massey 1969).

\section{Results}

No gross changes in the morphology of the mouse mandible were seen following denervation during the experimental period. Autoradiographic grains were seen as early as $15 \mathrm{~min}$ after ${ }^{3} \mathrm{H}$-proline administration. Figure 1 presents the typical autoradiographic appearance of osteoblasts after denervation. The labeled bone at the end of the experiment (150 days) showed many apparently empty lacunae following denervation (Fig. 1A). Intense activity was seen over the periosteal osteoblasts mesial to the first molar at all time periods examined in both the denervated and the sham operated animals (Figs. $1 \mathrm{~B}, 2$ ). Maximum uptake of ${ }^{3} \mathrm{H}$ proline occurred 60 days after surgery and $30 \mathrm{~min}$ after the administration of the 

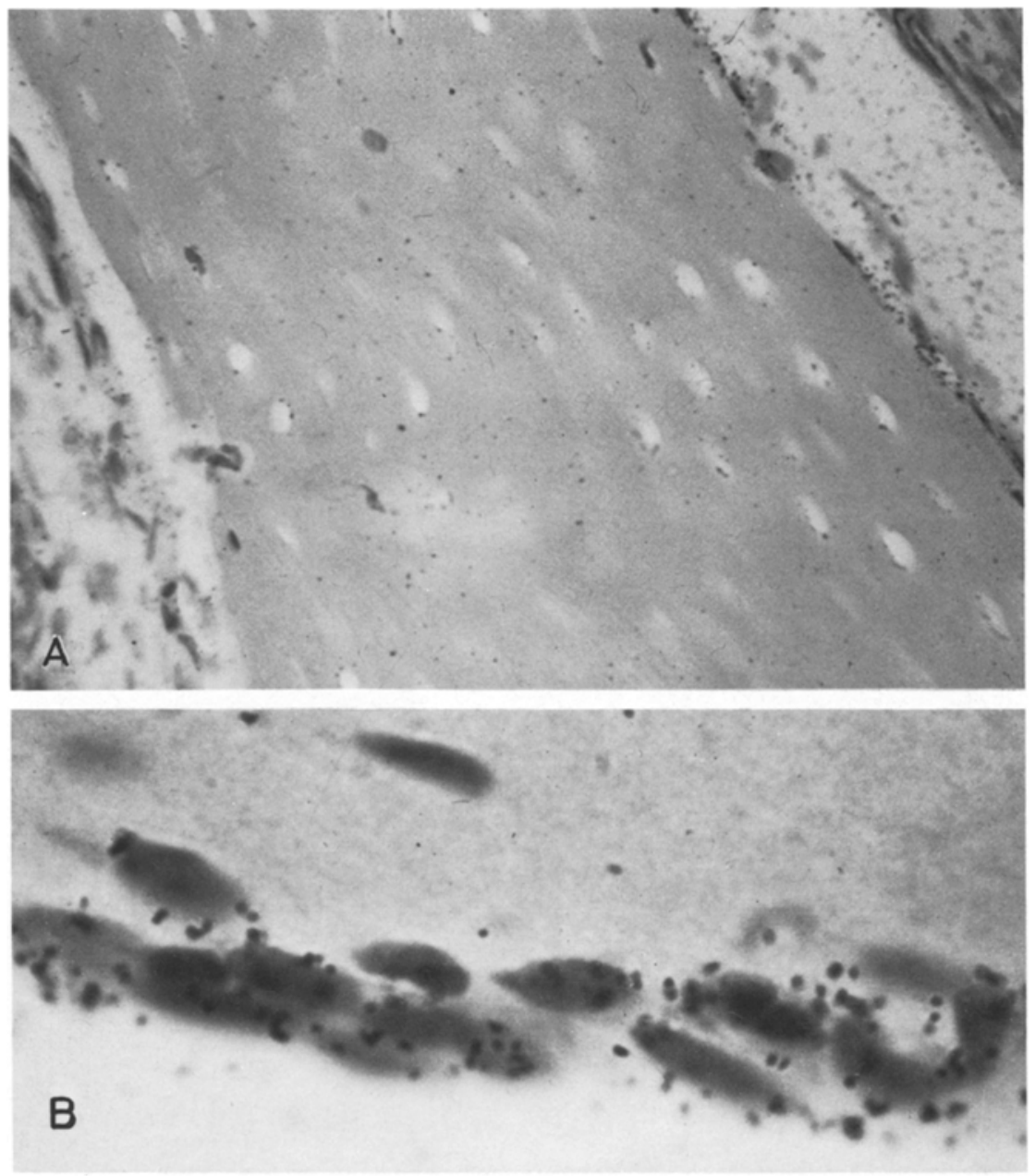

Fig. 1 A, B. Autoradiographs of mouse mandibular bone $30 \mathrm{~min}$ after ${ }^{3} \mathrm{H}$-proline administration (hematoxylin, eosin): A mesial to first molar 150 days after denervation $\times 250$. B Osteoblasts mesial to first molar 30 days after denervation $\times 1,000$

isotope for both the denervated and the sham-operated animals (Table 1). At 13 of the 15 time periods tested, osteoblasts showed significantly less label following denervation. The rate of uptake of ${ }^{3} \mathrm{H}$-proline was estimated by the slope of the linear regression equation. The osteoblasts of sham-operated and denervated bone differed in this rate of uptake at all time periods tested, 15 to 30,30 to 60,60 to 90 and 90 to 150 days (Table 2). Between 15 and 60 days following surgery, osteoblasts of denervated bone incorporated ${ }^{3} \mathrm{H}$-proline at a reduced rate as compared to those of sham operated animals. The rate of uptake of the isotope between 60 and 150 days following surgery declined in both denervated and sham-operated bone but more gradually in the former (Table 2). 


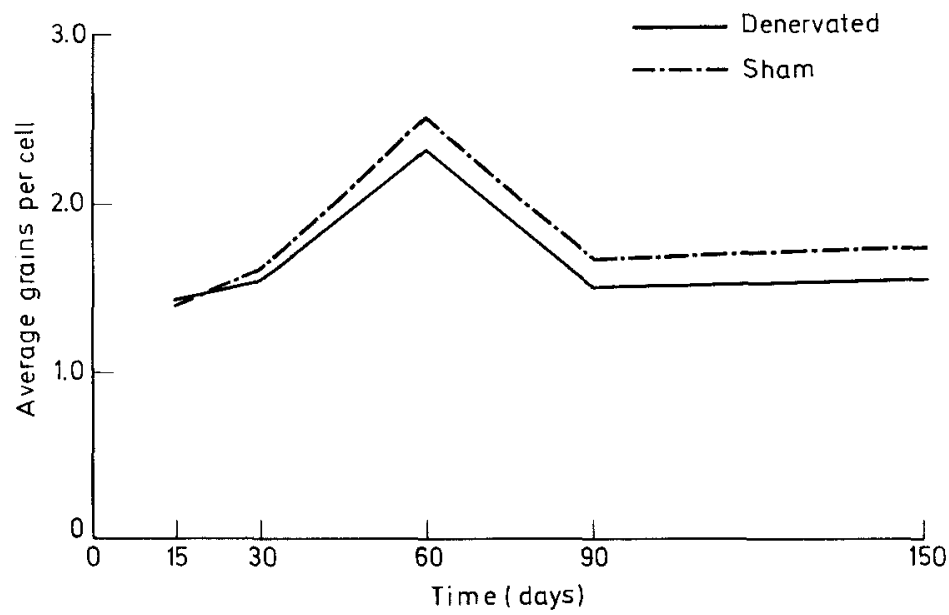

Fig. 2. Uptake of ${ }^{3} \mathrm{H}$-proline by periosteal osteoblasts of denervated and sham-operated bone 15 to 150 days after surgery. Isotope administered $30 \mathrm{~min}$ prior to killing on days $15,30,60,90$, and 150

Table 1. Mean \pm standard deviation of autoradiographic grain counts over periosteal osteoblasts after ${ }^{3} \mathrm{H}$-proline administration ${ }^{\mathrm{a}}$

\begin{tabular}{|c|c|c|c|c|}
\hline \multirow[t]{2}{*}{$\begin{array}{l}\text { Days After } \\
\text { Surgery }\end{array}$} & & \multicolumn{3}{|c|}{$\begin{array}{l}\text { Osteoblasts } \\
\text { Time Post-Injection (min) }\end{array}$} \\
\hline & & 15 & 30 & 60 \\
\hline 15 & $\begin{array}{l}\mathrm{D} \\
\mathrm{S}\end{array}$ & $\begin{array}{l}1.43 \pm 0.08 \\
1.45 \pm 0.01\end{array}$ & $\begin{array}{l}1.43 \pm 0.14 \\
1.39 \pm 0.03\end{array}$ & $\begin{array}{l}1.44 \pm 0.02^{\mathrm{b}} \\
1.50 \pm 0.01\end{array}$ \\
\hline 30 & $\begin{array}{l}D \\
S\end{array}$ & $\begin{array}{l}1.55 \pm 0.01^{\mathrm{b}} \\
1.59 \pm 0.01\end{array}$ & $\begin{array}{l}1.53 \pm 0.01^{b} \\
1.61 \pm 0.02\end{array}$ & $\begin{array}{l}1.55 \pm 0.05^{\mathrm{b}} \\
1.70 \pm 0.001\end{array}$ \\
\hline 60 & $\begin{array}{l}\mathrm{D} \\
\mathrm{S}\end{array}$ & $\begin{array}{l}1.84 \pm 0.33^{b} \\
2.43 \pm 0.04\end{array}$ & $\begin{array}{l}2.33 \pm 0.10^{\mathrm{b}} \\
2.54 \pm 0.02\end{array}$ & $\begin{array}{l}2.11 \pm 0.05 \\
1.55 \pm 0.07\end{array}$ \\
\hline 90 & $\begin{array}{l}\mathrm{D} \\
\mathrm{S}\end{array}$ & $\begin{array}{l}1.62 \pm 0.06 \\
1.63 \pm 0.04\end{array}$ & $\begin{array}{l}1.52 \pm 0.02^{b} \\
1.64 \pm 0.01\end{array}$ & $\begin{array}{l}1.50 \pm 0.02 \\
1.63 \pm 0.11\end{array}$ \\
\hline 150 & $\begin{array}{l}\mathrm{D} \\
\mathrm{S}\end{array}$ & $\begin{array}{l}1.49 \pm 0.11^{b} \\
1.60 \pm 0.04\end{array}$ & $\begin{array}{l}1.57 \pm 0.03^{b} \\
1.73 \pm 0.09\end{array}$ & $\begin{array}{l}1.54 \pm 0.03^{b} \\
1.69 \pm 0.03\end{array}$ \\
\hline
\end{tabular}

a Sample size for each mean and its standard deviation is not less than 400 cells

${ }^{\mathrm{b}}$ Mean values between sham (S) and denervated (D) animals are significantly different $(P<0.05)$

\section{Discussion}

Both autonomic and sensory nerves have been demonstrated in bone; however, their function remains unclear. Several investigators reported sympathectomy to enhance bone growth while others have failed to find such growth stimulation in a variety of laboratory animals (Review by Singh et al. 1981). 
Table 2. Regression analyses of grain count data over periosteal osteoblasts $30 \mathrm{~min}$ after ${ }^{3} \mathrm{H}$-proline administration for the time interval specified

\begin{tabular}{|c|c|c|c|}
\hline \multirow{2}{*}{$\begin{array}{l}\text { Days } \\
\text { Post-Surgery }\end{array}$} & \multicolumn{3}{|c|}{ Regression Slope ${ }^{2}$} \\
\hline & Denervated & Sham-Operated & $t^{\mathrm{b}}$ \\
\hline $15-30$ & 0.09 & 0.22 & 22.04 \\
\hline $30-60$ & 0.80 & 0.93 & -64.12 \\
\hline $60-90$ & -0.91 & -0.90 & 44.00 \\
\hline $60-150$ & -0.38 & -0.41 & 13.05 \\
\hline
\end{tabular}

a Regression slope is the " $B$ " value from the appropriate regression equation: $Y=A+B X$

b All $t$ values indicate significant differences between sham-operated and denervated bone, $P<0.05$

Recent reports have shown an increased number of nerves in osteoarthritic femoral heads (Reimann and Christensen 1972) and accelerated healing of fibular fractures in denervated bone (Frymoyer and Pope 1977). Regional differences may exist in the functional role of nerves in bone. For example, Wertz and Donaldson (1979) reported that, although the newt limb requires nerves for regeneration, jaw regeneration may be independent of such neural control. In general, denervation studies have to be cautiosuly interpreted regarding neural control over cellular activity since such studies were largely conducted on limbs where a spectrum of muscular, circulatory, or disuse effects are combined (Allision and Brooks 1921; Greiser and Trueta 1958; Dubner et al. 1978). The experimental model selected in the present study, therefore offered certain clear advantages: (1) The inferior alveolar nerve is not a mixed nerve and is not known to provide innervation to muscles that move the mandible. (2) Since the two halves of the mandible move as a unit, any disuse effects would be further reduced. (3) The inferior alveolar artery was visualized but left intact thus keeping circulatory and sympathetic disturbances to a minimum.

Trauma is known to cause regional acceleration in osteoblastic activity (Dubner et al. 1978). Therefore, it could be reasoned that perhaps the uptake of ${ }^{3} \mathrm{H}$-proline was higher in the osteoblasts of sham-operated animals than in those of the contralateral unoperated side, while osteoblasts of the denervated side had remained unchanged in such uptake. In that case, osteoblasts from denervated bone will show lower uptake than those of sham-operated animals as observed in the present report, but the effects would not necessarily be due to denervation. That position appears highly unlikely in view of the following: (1) Although a complete analysis of the contralateral (unoperated) side is not presented in this study, there is no significant difference in the uptake of ${ }^{3} \mathrm{H}$-proline by osteoblasts mesial to the first molar between the sham-operated and unoperated sides, though data obtained nearer the site of bone injury might reveal differences. (2) More importantly, if denervation per se were to result in no change in cellular activity, osteoblasts from denervated and sham-operated mandibles ought to be similar since the only difference between the two is nerve resection. Soft tissues and bone were similarly traumatized in both cases.

Although the inferior alveolar artery is left intact, the severe disruption of the blood supply of the periosteum occuring in our surgical procedure may alter the 
vascular supply of bone significantly. Nevertheless, for the reasons stated above, the differences in osteoblastic activity between the sham-operated and denervated mandibles could only be accounted for by nerve resection. The periosteal blood supply was similarly interrupted in both sham-operated and denervated rats.

Although quantitative data were not obtained, many of the lacunae appeared empty following nerve resection. An increased proportion of apparently empty lacunae has also been reported in aging BNL mice (Tonna 1966). Since the animals in the present experiment were not old even at the end of the study (180 days), it appears that denervation might have caused an early death of osteocytes which, had the tissue been innervated, might have remained viable. However, immediately adjacent to the area of empty lacunae, the osteoblastic layer was fully functional as evidenced by the density of autoradiographic grains. This observation indicates great plasticity in the population of osteoblasts even after denervation. ${ }^{3} \mathrm{H}$-proline uptake increased in osteoblasts in both sham-operated and denervated mandibles until 90 days of age. At all but the first time-periods (15 days), denervated bone showed reduced ${ }^{3} \mathrm{H}$-proline labeling compared to bone from sham-operated animals. This decrease following denervation probably reflects lowered cellular activity and a concomitant decline in the synthesis and extrusion of matrix proteins.

Since the vascular and sympathetic nerve supply of the mandible was presumably not damaged, it would seem that the observations are a result of denervation which affects the sensory feedback from the periosteal receptors (Sakada 1967). The reduction in the rate of synthesis suggests the interruption of a "trophic" influence of the nerve. Skopakoff and Stiefel (1972) reported decreased collagen synthesis after resection of the inferior alveolar nerve in dogs. Moss (1972) suggested that similar trophic controls exist for capsular functional matrices, which may passively regulate the position of both the skeletal unit and the periosteal matrices. In postulating a possible neurotrophic influence on bone, it would be important to define neurotrophism as "regulation not mediated by nerve impulses or by functional demand" (Dubner et al. 1978). Recent investigations have pointed out that only by experiments in which nerve impulse conduction can be selectively dissociated from axoplasmic flow, is it possible to demonstrate definite neurotrophism (Albuquerque et al. 1974). It is not possible, therefore, to unequivocally demonstrate such a "neurotrophic" factor by the present study. Although functional and circulatory disturbances were kept to a minimum by selecting a sensory nerve in the mandible, altered sensibility certainly resulted. It has been pointed out by several investigators (Moss 1972; Goodwin and Luschei 1974; Behrents 1975; Dubner et al. 1978) that such altered sensibility can influence facial dimension. Nevertheless, the present report offers the first direct evidence of the modulation of osteoblastic activity by sensory innervation.

Since the assessment of osteoblastic activity in the present report was carried out some distance away from the site of surgical trauma, it is not possible to estimate the effects of short- or long-term sensory denervation on the repair of bone fractures. It also remains to be determined what if any would be the effects of long-term denervation if it is carried out very early during development. The grain counts are uniformly low in both experimental and control bones but are quite consistent with the reported data on the uptake of a variety of labeled amino acids by osteoblasts (Tonna 1977). 
Following denervation, osteoblasts clearly exhibited a lower metabolic activity. Differences between sham-operated and denervated specimens were maximal 60 days after denervation. This time factor is perhaps a function of the normal healing process in bone. At longer intervals after trauma (90 to 150 days), the differences between denervated and sham-operated bone were greatly reduced and became attenuated perhaps due to a compensatory mechanism secondary to neurotrophic influences on bone-cell activity. Neurotrophic influences on osteoblast activity have not yet been unequivocally demonstrated (Dubner et al. 1978) and it is possible to maintain the skeleton under conditions of complete denervation (Corbin and Hinsey 1939). It is interesting to note, however, that some evidence points to the presence of neurotrophism in dentin deposition (Kroeger 1968; Avery et al. 1974; Byers and Kish 1976).

\section{References}

Albuquerque FX, Warnick JE, Sansone FM, Onur R (1974) The effects of vinblastine and colchicine on neural regulation of muscle. In: Drachmann DB (ed) Trophic Functions of the Neuron. Vol 228, NY. Acad Sci, New York, pp 224-243

Allison N, Brooks B (1921) Bone atrophy. An experimental and clinical study of the changes in bone which result from non-use. Surg Gyn Obstet 33:250-260

Ascenzi A, Bell GH (1972) Bone as a mechanical engineering problem. In: Bourne GH (ed) The Biochemistry and Physiology of Bone, 2nd ed. Academic Press, New York, pp 341-345

Avery JK, Cox CF, Corpron RE (1974) The effects of combined nerve resection and cavity preparation and restoration on response dentine formation in rabbit incisors. Arch Oral Biol 19:539-548

Behrents RG (1975) The influence of the trigeminal nerve on facial growth and development. Master's Thesis. Case Western Reserve University, $208 \mathrm{pp}$

Byers MR, Kish SJ (1976) Delineation of somatic nerve endings in rat teeth by radioautography of axontransported protein. J Dent Res 55:419-425

Corbin KB, Hinsey JC (1939) Influence of the nervous system on bone and joints. Anat Rec 75:307-317

Dixon WJ, Massey FJ (1969) Introduction to statistical analysis. 3rd ed. McGraw-Hill, New York, pp 193-216

Dubner R, Sessle BJ, Storey AT (1978) The neural basis of oral and facial function. Plenum Press, New York, pp 379-361

Frymoyer JW, Pope MH (1977) Fracture healing in the sciatically denervated rat. J Trauma 17:355-361

Goodwin GM, Luschei ES (1974) Effects of destroying spindle afferents from jaw muscles on mastication in monkeys. J Neurophysiol 37:967-981

Greiser M, Trueta J (1958) Muscle action, bone rarefaction and bone formation. J Bone Joint Surg 40B: $282-311$

Guth L (1969) "Trophic" effects of vertebrate neurons. Neurosci Res Prog Bull 7:1-73

Kroeger DC (1968) Possible note of neurohumoral substances in the pulp. In: Finn SB (ed) Biology of the dental pulp organ. A symposium. Univ Alabama Press, Birmingham, pp 333-352

Moss ML (1972) An introduction to the neurobiology of oro-facial growth. Acta Biotheror 21:236-259

Reimann 1, Christensen SB (1977) A histological demonstration of nerves in subchrondral bone. Acta Orthop Scandiniv 48:345-352

Robbins N (1967) The role of the nerve in maintenance of frog taste buds. Exp Neurol 17:374-380

Sakada S (1967) Characteristics of innervation and nerve endings cats' mandibular periosteum. Bull Tokyo Dent Coll 8:77-94

Singer M (1952) The influence of the nerve in regeneration of the amphibian extremity. Quart Rev Biol 27:169-200

Singer M, Craven L (1948) The growth and morphogenesis of the regenerating forelimb of adult Triturus following denervation at various stages of development. J Exp Zool 108:279-308

Singh IJ, Klein RM, Herskovits M (1981) Autoradiographic assessment of ${ }^{3} \mathrm{H}$-proline uptake by osteoblasts following guanethidine-induced sympathectomy in the rat. Cell Tissue Res $216: 215-220$ 
Skopakoff C, Stiefel A (1972) Dysplastic aberrations in the dentin of dogs' teeth due to the interruption of their blood supply and innervation. Investigated with the aid of tetracycline stains. In: Schumaker GH (ed) Morphology of the maxillo-mandibular apparatus. VEB Georg Thieme, Leipzig, E Ger, pp 90-94

Thornton CS (1968) Amphibian limb regeneration. Adv Morphol 7:205-249

Tonna EA (1966) A study of osteocyte formation and distribution in aging mice complemented with ${ }^{3} \mathrm{H}-$ proline autoradiography. J Geront 21:124-130

Tonna EA (1977) Aging of skeletal-dental systems and supporting tissues. In: Finch CE, Hayflick L (eds) Handbook of the biology and aging. Van Nostrand, New York, p 470-495

Wertz RL, Donaldson DJ (1979) Effects of X-rays on nerve-dependent (limb) and nerve-independent (jaw) regeneration in the adult newt. Notrophthalmus viridescens. J Embryol Exp Morphol 53:315325

Yntema CL (1959) Regeneration in sparsely innervated and aneurogenic forelimbs of Amblystoma larvae. J Exp Zool 140:101-124

Accepted January 12, 1981 